\title{
Social Transformation in Early Childhood Education: An Ethnographic Study in Widhatul Ummah Kindergarden in Makassar, Indonesia
}

\author{
Juwanita Sahid ${ }^{1, *}$ Nurul Ilmi Idrus ${ }^{1}$ Hamka Naping ${ }^{1}$ Munsi Lampe ${ }^{1}$
}

\author{
${ }^{1}$ Anthropology Doctoral Study Program, Hasanuddin University, Makassar, Indonesia \\ *Corresponding author.Email: binpaud@gmail.com
}

\begin{abstract}
Globalization has affected the Indonesian people's lives. This study aims to examine the socio-cultural transformation of Wihdatul Ummah Kindergarten in Makassar. It is a qualitative research using an ethnographic approach. The research participants are parents, teachers, leaders and school staff. The Islamic education system initiated by Wahdah Islamiah is not as easy as imagined. Internal and external conflicts, such as stigma and stereotypes as exclusive education, etc. are indisputable. Currently, it is gaining a significant positive response. Islamic religious values could be well developed and nurtured in Wihdatul Ummah Kindergarten. These values undergo a lengthy enculturation process and involve a variety of stakeholders as well as the environment. There are, however, supporting and inhibiting factors its development and implementation.
\end{abstract}

Keywords: Kindergarten, ethnography, social transformation

\section{INTRODUCTION}

In the 2000s, the inclusion of a global idea of education for children declared through the EFA (Educational For All) movement for the first time in 1990 in Thailand was later confirmed in the Dakkar Declaration in 2000. In 1922, Ki Hajar Dewantara (1889-1959) founded the Lare Park or the Children's Park, eventually developing into the Indria Park or what we later know as a Kindergarten. Ki Hajar Dewantara has laid the foundations of a culture-oriented national education through the establishment of a student park. Ki Hajar Dewantara asserted that culture is the basis or basis of education, and education should be in accordance with the nature of life stored in the customs of the society (Sularto, 2016).

The existence of kindergartens is officially regulated in Law No. 4/1950, which stipulates children's education as part of the national education system, and this was later reinforced by the establishment of public kindergartens in the 1960s. The government developed policies on education through the National Education System Law No. 20/2003. At the level of children's education and early age, the role of educational institutions is very strategic to instill moral, cultural and national values. The existence of early childhood education institutions (PAUD) has gained a large space in the midst of modernization of community life, the rise of a new middle class (Seda, 2012).

The general purpose of this study is to explore in depth the phenomenon of transformation or social cultural processes of early childhood institutions in Wihdatul Ummah kindergarten.

\section{RESEARCH METHODS}

This research employs a qualitative approach, which aims to understand social phenomena in their entirety (holistically) and deeply (Spradley, Elizabeth, \& Amirudin, 1997). Social phenomena in early childhood education institutions (PAUD) are revealed in full natural settings based on the philosophy of phenomenology.

This research only focuses on one institution of early childhood education, namely in Wihdatul Umma kindergarten in Makassar City. This location was chosen purposively, with the consideration of the social class category and its religious-based method that has existed for a considerable period, and received a positive response amid competitive socio-cultural changes. The kindergarten is also representative as a resilient institution that has a strong Islamic ideology.

The data of this study consist of: (1) Primary data; (2) Secondary data. is the former refer to data entirely obtained through in-depth interviews, observation and participation and focus group discussions (FGD). The latter consist of data collected from various documents or reports from related agencies, such as schools, education agencies and related government.

The data analysis of this research was carried out as a qualitative analysis procedure that went through three processes: (1) Perform data reduction. This process begins by gathering all primary data (interview transcripts, observations and FGDs), reading them over and over again, selecting the data, and then discarding unnecessary data; (2) Categorizing. This second step is carried out to 
group similar issues or similar topics of discussion. It is at this stage that the topic findings regarding the formation of a tarbiah (education)-based Wahdah generation, Islamic values in the content of education and the meaning of parents regarding Wahdah education are discovered; and, (3) Data interpretation. This last stage contains the process of data description by synthesizing the results of interviews, observations and FGDs.

\section{RESULTS AND DISCUSSION}

Wahdah Islamiah as a social movement in upholding the amar ma'ruf nahi munkar initially did not cover the whole society (ummah), but was limited to certain circles. Early activism from the establishment of Wahdah Islamiah (Fathul Muin Foundation) was an "exclusive" organization. This exclusivism is indicated in the process of "separating" the activists who founded the Fathul Muin Foundation and Muhammadiyah from 1986 to its institutionalization in 1998. It was after this stand that the movement was very intensive and targeted students (Jurdi, 2007).

The initial exclusivism that occurred at Wahdah Islamiah in the search for this research was marked by the emergence of educated groups (students and academics) as the main members. This group positioned themselves as " the elite group" who then carried out da'wah to all corners of the Makassar area. The enthusiasm of receiving good da'wah by the community was motivated by the ability of the group's knowledge, and knowledge of its members who were mostly educated. This position is then very attached to Wahdah Islamiah as an exclusive group.

This initial journey shows how Wahdah Islamiah was transformed from an "exclusive movement towards an inclusive movement". The members of Wahdah Islamiah believe that the development and empowerment of the ummah is an investment in the realization of Islamic teachings at the individual, family, community level, to the level of the nation and state. The inclusiveness of Wahdah Islamiah is thus situational as the country's political situation changes.

This change is also not easy among Wahdah Islamiah's internal circles, including for the teachers. Mentari (38 years) felt that Wahdah Islamiah was initially an exclusive organization. She stated that:

"... In the early days I felt that this school contained only our children. So as an educator I know exactly the child and his family background because his parents are equally active in Wahdah. I often felt as if I was withdrawing from the people, setting up my own school for our children, even though I didn't. But the early leaders of the foundation still could not accept the students at random from outside. ... so if you think about it, just the people (our fellow). Everywhere you find it, that's all. I really thought why Wahdah's propaganda became less extensive because it contained only us. Did the foundation's leaders not think of developing more broadly? Yes, in the beginning I still wondered like that".

Mentari's statement above confirms the initial conditions of Wahdah Islamiah as an exclusive institution. As a formal institution established by Wahdah Islamiah, the kindergarten was indeed considered as a form of "exclusivity" at the first place. In the continuation of this interview session, Mentari (38 years) explained how the conditions of Wahdah Islamiah were far more inclusive today.

"... If now Mashallah. Our schools are no longer filled by our children, but the children of our relatives, our neighbors, and some even from outside the island and new to Makassar. Finally, it became like our family. This is thankfulness, thank God. It means Wahdah and her school can be widely well-received by everyone ".

More specifically, this change occurred after a decade (ten years) of the establishment of this educational institution. Wahdah Islamiah's development from an exclusive to inclusive organization also had implications for the same change in the educational institution that she initiated.

Wahdah Islamiah was eventually also marked as a moderate and accommodating organization on broad muamalah issues, but not for matters of faith and worship. Worldly issues, such as social, economic and political issues or those dealing with community welfare were positively accepted. Wahdah Islamiah's accommodative attitude is very prominent in the social and educational fields. The construction of various public schools, in Makassar and other regions provide evidence to significant changes occurring in Wahdah Islamiah.

The strengthening of the issue of "the emergence of new religiosity" (Hefner, 2010) is currently increasingly encouraging the growth and development of Wahdah Islamiah educational institution. People began to send their children to Islamic schools, such as Wihdatul Ummah. The inclusiveness of Islamic Wahdah is accompanied by changes in society that lead to the poles of religiosity. Another phenomenon that also marks this change is the emergence of Islamic market segmentation or the "halal market". Products with "Islamic" and "halal-labeled" packaging are becoming increasingly popular in society, such as cosmetics, clothing, and various other properties (Endah, 2018; Aisyah, 2016; Rohmatun, \& Dewi, 2017; Sahir, Ramadhani, \& Tarigan, 2016).

Wihdatul Ummah kindergarten has become an inclusive institution that is aligned with the needs of the community. Islamic values are obviously also another advantages that the institution offer to public. This kindergarten could eventually deny accusations toward Wahdah Islamiah as an exclusive or closed institution.

Civil values that support the establishment of a cosmopolitan society include: first, inclusivism, namely self-disclosure to outside elements through the ability to appreciate and select constructively. Second, humanism, in the sense of a perspective that treats humans solely because of their humanity, not because of any other cause beyond that. Included in humanism here is the egalitarian nature of looking at humans as equals. Third, tolerance, 
namely the existence of space and greatness of the soul in dealing with differences. Fourth, democracy which gives space for freedom of thought and the delivery of criticism (Kartanegara, 2007). The values that were later tried were achieved in the Wahdah Islamiah transformation. Movement transformation includes inclusivism, humanism, tolerance, and democracy.

Although inclusive religious attitudes have a solid basis, the realization of the effort does not take place smoothly. The ideology of "returning to the Qur'an and Sunna" largely embraced by contemporary religious movements, often endorsing a number of violent campaigns, such as apostasy, assault and terrorism, present difficult challenges for inclusive religious attitudes needed for the establishment of a cosmopolitan society. This is because this contemporary religious movement group identifies the West, in this sense Non-Muslims and Muslims who are considered not in line with thinking. as enemies. Here, inclusive religious attitudes are forced to deal with radicalexclusive religious attitudes that do not leave room for dialogue and compromise in resolving common problems, both nationally and globally. The myth of Wahdah Islamiah as an Islamic organization of hard-line and exclusive movements is slowly being pushed aside.

Another challenge faced by Wahdah Islamiah's transformation into an inclusive institution is the strength of figh which introduces a less positive perspective, such as rigid and linear intolerance towards other religious communities. A number of figh books tend to show discriminatory thoughts towards people of other religions. In the tradition of jurisprudence, the relationship between religions, Muslims and Non-Muslims, apparently has not yet received a fair settlement because it is motivated by several reasons, namely (1) jurisprudence was written at a time when the relationship between Muslims and NonMuslims was not so conducive, (2) figh written at the time when the internal situation of Muslims is not so solid, and (3) there are religious symbols that implicitly advocate a hard attitude towards other religions. these challenges have become the "thorn in the flesh" that continues to be opposed by the Wahdah Islamiah education movement, particularly in the growth and development of Wihdatul Ummah kindergarten, as revealed by Sinar (37 years) a teacher that:

"... The early establishment of kindergarten was not only challenged from the outside, but also from within. The Ustadz and Ustazah seniors, especially those who are very well read, are a kind of textual, and they really oppose it if the school is involved in general activities. Especially if you know that the school embraces the community, well sometimes we are immediately criticized to the utmost ".

Conservative jurisprudence tends to close itself to liberalism, pluralism and secularism. The three paradigms actually have compatibility with Islam which upholds freedom, for example freedom of religion and freedom of thought. Islam values diversity as a human need and God's destiny. Islam also rejects dominance in the religious sphere and opposes the need for an Islamic state. Such suspicions used to be blamed on Wahdah Islamiah groups, including Wihdatul Ummah kindergarten as a concrete representation of their movement.

In accordance with the demands of local wisdom, early Islamic education carried by Wahdah Islamiah is expected to be responsive to the diversity of religions, cultures and communities in Indonesia as a real reality that requires seriousness in managing it. In addition, the insistence on the current of globalization with its positive and negative sides is increasingly inevitable as if demanding to have an inseparable global insight from the roots of Indonesia and Islam. Without wisdom, pluralism is like a "fire in the husk" which has the potential to suppress the building blocks of national and state life, while without the right global insight, the current of globalization will drag into the vortex of calamity, such as violent behavior in the name of religion or materialistic lifestyle. In the most basic level of child development, this will be the best capital in an increasingly competitive development.

Thus, educational activities are needed to foster multicultural wisdom and global awareness of students, namely inclusive education. Later, this generation will be able to play a role in caring for diversity and making use of it to achieve the benefits of living together, and to be able to respond appropriately to the current of globalization. This means that early Islamic education has an important mission to bring students closer to the guidance of religion and to transform religious values that are inclusive-multicultural to them. Religious education should be more "dialogic" so that educational activities could nourish the growth and development of multicultural wisdom and learners' global insights

As a religious movement, this polarization and various negative accusations have unquestionable consequences. The intersection between dominant ideology and minor ideology has always been a contest that takes place in such a long round. The tension between doctrine and the world is a never-ending problem in a society undergoing a process of modernization (Ali \& Effendy, 1986).

Fitri (32 years), one of the teachers at Wihdatul Umma kindergarten, talked about the weight of dismissing the prospective parents' perceptions about the stereotype of Wahdah Islamiah institution:

"... First of all, this school only contains children from Wahdah cadres, so it can be said that the beginning is still within the scope of fellow members. Then from the members invite relatives and neighbors, but there are also other individuals who are interested. Well, the problem is that new people who don't understand Wahdah or don't have Wahdah knowledge, feel very anxious if their children are admitted to this school. There are some parents who are too worried their children will be indoctrinated, there are also those who worry that their children will be very closed and hard to get along with friends outside of school ".

Fitri's conversation above, shows how the development of educational institutions initiated by Wahdah Islamiah is still limited for cadres. The flow of information and 
technology that develops, making some of the parents who do not have complete knowledge about Wahdah Islamiah become very alarmed.

On one hand, there is hope to send children to Islamic schools to obtain good religious knowledge. On the other hand, there is a concern that there is dogmatic learning materials, as expressed by Bunga (27 years), a parent of students, that:

"... I still doubt it in the beginning. It's because the teachers are covered in veils, I wondered how to communicate with the children later. Then there are also those who say around the neighborhood, he said the children who study there will have difficulty getting along, too pious. There are also those who say later that jihad is taught. Now, as far as I'm concerned, jihad is war. Had thought maybe this could be called a terrorist later. But because I was very curious, because there was a teacher in the school who often played with my child and was good at counting and very polite, I had never heard dirty and rude talk, I ventured to his school. I ask questions about how the teaching is and what the children will achieve. It turned out that everything was beyond my expectations, the way of learning was different and the children were immediately taught independence. Since that time, I was sure and until now there have never been negative gossip before".

This quote implies there us a negative image towards Wahdah Islamiah schools and kindergarten.

In the focus group discussion with parents, it was also revealed how other parents found negative situations to be positive. Parents actually become agents to construct a positive image of Wahdah Islamiah education. In the few years after the entry of non-cadre (general) students, the number of registrants has experienced a significant increase.

Other challenges faced are not only related to Wahdah Islamic and community issues (external parties), but also among fellow management. Efforts to get out of the vortex of stereotypes are responded in different ways. Among these methods are disagreement between fellow Wahdah Scientists. Indah (43 years old) as a headmaster explained how conflicts occurred between her and the foundation's officials, as follows:

"In 2007 I tried to introduce children and school to the public. I take the children in general competition events so they get to know each other with other schools. I included a children's television program with a competition. Alhamdulillah our children won first place. I am very proud, I am happy because Wihdatul Ummah kindergarden is known by many people, especially other schools. We go home with the trophy ...".

"... In short, we were happy at that time. But I was surprised to be called by the head of the foundation (YPWI). They gave me SP 1 (warning letter 1). He said I had taken the children to public places while we knew as teachers we had to maintain Islamic values. Not to mention because I covered hijab improperly so ".

\section{CONCLUSION}

Efforts to counter stereotypes or bad images that were attached to Wahdah Islamiah are still often met with pros and cons. The more self-exclusion is promoted, the stronger the stereotype survives. Appearing in public and introducing the educational achievements of Wahdah Islamiah are the best ways to ward off. The methods are also effective to promote Wahdah Islamiah education, so that it can continue to grow and be widely accepted by society.

\section{REFERENCES}

Aisyah, M. (2016). Consumer demand on halal cosmetics and personal care products in Indonesia. $\mathrm{Al}$ Iqtishad: Jurnal Ilmu Ekonomi Syariah, 9(1), 125-142.

Ali, F., \& Effendy, B. (1986). Merambah jalan baru islam: Rekontruksi pemikiran islam indonesia masa orde baru. Jakarta: Mizan.

Endah, N. H. (2018). Behavior of purchasing halal labeled cosmetics by indonesian consumers. Journal of Economics and Development, 22(1), 11-25.

Hefner, R. W. (2010). Religious resurgence in contemporary Asia: Southeast Asian perspectives on capitalism, the state, and the new piety. The Journal of Asian Studies, 69(4), 1031-1047.

Jurdi, S. (2007). Sejarah wahdah islamiyah. Yogyakarta: Kreasi Wacana.

Kartanegara, M. (2007). Mengislamkan nalar: Sebuah respon terhadap modernitas. Jakarta: Erlangga.

Rohmatun, K. I., \& Dewi, C. K. (2017). Pengaruh Pengetahuan Dan Religiusitas Terhadap Niat Beli Pada Kosmetik Halal Melalui Sikap. Jurnal Ecodemica, 1(1), 27-35.

Sahir, S. H., Ramadhani, A., \& Tarigan, E. D. S (2016). Pengaruh gaya hidup, label halal dan harga terhadap keputusan pembelian kosmetik wardah pada mahasiswa Program Studi Manajemen Fakultas Ekonomi Universitas Medan Area Medan. Jurnal Konsep Bisnis dan Manajemen, 3(1), 47-61.

Seda, F. (2012). Kelas Menengah Indonesia: Gambaran Umum Konseptual. Jurnal Prisma, 31(1), 3-13.

Spradley, J. P., Elizabeth, M. Z., \& Amirudin. (1997). Metode etnografi. Yogyakarta: Tiara Wacana Yogya. Sularto, S. (2016). Inspirasi kebangsaan dari ruang kelas. Jakarta: Penerbit Buku Kompas. 